\title{
The presence and role of progesterone receptor in the ovaries of postmenopausal women who have not applied hormone replacement therapy
}

\author{
Andrzej Starczewski ${ }^{1}$, Agnieszka Brodowska ${ }^{1}$, Maria Laszczyńska ${ }^{2}$, \\ Malgorzata Piasecka ${ }^{2}$
}

${ }^{1}$ Department of Reproduction and Gynecology, ${ }^{2}$ Laboratory of Histology and Developmental Biology, Pomeranian Medical University, Szczecin, Poland

\begin{abstract}
At present, not much is known about progesterone receptor (PR) expression and localization in postmenopausal women ovaries. In the ovaries of reproductive age women, PR is localized in internal theca and granulosa cells, corpus luteum, ovary surface epithelium (OSE) and in stroma. PR expression depends on the serum concentration of progesterone, estrogen, gonadotropin and androgen. The goal of the conducted studies was to examine PR localization and expression in the ovaries of postmenopausal women who have not applied hormone replacement therapy so far. Also, the correlation was examined between PR expression and localization in the ovaries, steroid and gonadotropin hormone serum concentrations, and influence of the time from the last menstruation. The material came from 50 postmenopausal women who had their ovaries removed due to non-neoplastic diseases. The women were divided into 3 groups (A, B, C) depending on the time from the last menstruation. The follitropin (FSH), luteotropin ( $\mathrm{LH})$, estradiol (E2), testosterone (T), androstendione (A) and dehydroepiandrosterone sulphate (DHEAS) concentrations in blood plasma were measured. Monoclonal mouse anti-human PR antibody was used for immunohistochemical detection (examination involved 50 postmenopausal ovaries). Between particular groups, $\mathrm{E}_{2}$ serum concentrations did not differ, but FSH, LH, T, A, DHEAS serum concentrations were significantly different. Immunohistochemical nuclear localization of PR in postmenopausal women ovaries was observed. PR expression was similar in all three groups (A, B, C). PR expression was observed in OSE nuclei and invaginations cysts deriving from the isolation of invaginated epithelium and metaplastic columnar epithelium and in stroma. In the ovaries of postmenopausal women who have not applied hormone replacement therapy so far, PR was detected in all three groups. Its expression did not depend on the time from menopause and was similar in all examined groups. FSH, LH, T, A, DHEAS serum concentrations did not influence PR expression.
\end{abstract}

Key words: Ovary - Progesterone receptor - Menopause - Women

\section{Introduction}

Progesterone receptors (PR) belong to the superfamily of ligand-dependent nuclear receptors [1]. They are proteins whose biological activity is affected by hormone-dependent phosphorylation [2,3]. PRs are widespread in an organism. In the reproductive organ they are found in an ovary, fallopian tube, muscle and mucous membrane of the uterus, cervix, vagina and nipple [4-7]. Presence of PR was also observed in pathologies of different type, among them:

Correspondence: M. Laszczyńska, Laboratory of Histology and Developmental Biology, Pomeranian Medical University, Żołnierska 48, 71-210 Szczecin, Poland; tel. (091-4800910), fax. (091-4800905),e-mail: laszcz@sci.pam.szczecin.pl endometriosis foci [8], benign tumors such as myomas $[6,9]$, as well as malicious tumors like mammary [10], ovarian $[11,12]$ and endometrial cancers $[13,14]$. This is interesting that in serous ovarian cancers, expression of this receptor is twice as high as in the healthy ovarian tissue [12].

PRs appear in two almost identical isoforms, namely PR-A and PR-B. They have the same places of function activation, but completely different transcription profiles $[15,16]$. PR-A mainly affects the activity of an ovary and uterus, and slightly mammary gland. Conversely, PR-B does not influence ovarian response, but it has an effect on the development of mammary gland, especially during pregnancy [17].

PRs are subjected to quantitative and qualitative changes depending especially on serum concentrations 
of LH and estradiol $[6,7,15,18,19]$, and to smaller degree on BMI and the levels of testosterone, androstendione, DHEAS, prolactin $[20,21]$ and progesterone [19].

PR immunolocalization and immunoexpression in female ovaries still arouse great interest of researchers. This is mainly because of the diagnosis and treatment of infertility, safety of hormone therapy in the perimenopausal period, as well as influence on oncogenesis in a nipple, endometrium and ovary. In the ovaries of reproductive-age women, PR is observed in stromal and surface epithelial cells, in the early stages of follicular development, and in theca and granular cells $[5,7,22,23]$. Its localization is also well known in corpus luteum $[23,24]$. PR expression changes during menstrual cycle. Progesterone through PR modifies ovarian follicular development, inhibits FSH-induced estradiol synthesis and creation of receptors for LH, and as a consequence maturation of follicles. In preovulatory follicles it affects growth of a follicle and ovulation. Besides, it controls the development, functioning and regression of a corpus luteum $[23,24]$.

The structure of a postmenopausal ovary significantly differs from that of reproductive-age. These differences are related to changes which concern both medulla and cortex. The division into these two structures becomes less distinct. Cortex loses its thickwalled character, the number of follicles reduces, and tendency to fragmentation of corpora albicantia can be observed. Epithelial inclusion cysts develop as a result of invagination of the surface epithelium and metaplasia of cuboidal epithelium. These cysts are usually present in ovarian stroma and surroundings of corpora albicantia. According to literature, $90 \%$ of epithelial ovarian carcinomas develops in such cysts or in the ovarian surface epithelium. Changes in medulla include fibrosis of the connective tissue, hyalinization of blood vessels, reduced blood vessel diameter, and altering blood vessel architecture [22,25-28].

It is known that after menopause, ovaries are not replaced by hormonally inactive connective tissue. They produce about $50 \%$ of circulating in blood androgens, especially testosterone and androstendione, and also estrogens, however their number is much smaller than before menopause $[29,30]$. On the contrary, it has not been examined yet, what is the dynamics of PR distribution during this period, or how it depends on the time from the last menstruation [30,31]. Also the role which PRs play in an ovary after menopause is unknown. Hence, the aim of this study was to assess PR distribution and expression in the ovaries of postmenopausal women depending on the lapse of time from the last menstruation and to determine correlation of PR expression with concentrations of estradiol, testosterone, dehydroepiandrosterone, androstendione and gonadotropin in postmenopausal women.

\section{Materials and methods}

Patients. The study involved 50 postmenopausal women whose ovaries were removed by laparotomy because of non-neoplastic diseases of the uterus. None of them used substitutive hormone therapy before. The Bioethical Commission gave its consent for this study. All cases were diagnosed at the Department of Reproduction and Gynecology, Pomeranian Medical University, Szczecin. The women were divided into 3 groups depending on the time which passed from the last menstruation. Group A (25 patients) consisted of women who had the last menstruation no more than 5 years earlier. Group B was composed of women (15 patients) whose menopause appeared 5 to 10 years earlier. Group $\mathrm{C}$ (10 patients) included patients whose last menstruation was over 10 years earlier.

Hormone measurements. ELISA method enzyme immunoassay kit (Spi-Bio France) was used to measure concentrations of follicle stimulating hormone (FSH), luteinizing stimulating hormone $(\mathrm{LH})$, estradiol $\left(\mathrm{E}_{2}\right)$, testosterone $(\mathrm{T})$, androstendione $(\mathrm{A})$ and dehydroepiandrosterone sulphate (DHEAS) in blood plasma in all the patients.

Morphology. Ovarian tissue (both cortex and medulla) was obtained during surgery. For morphological studies, ovaries were fixed in Bouin `s solution and $4 \%$ formalin, and embedded in paraffin. Sections were cut from the respective parts of ovaries. Morphological analysis was done after hematoxylin-eosin $(\mathrm{H}+\mathrm{E})$ staining.

Immunohistochemical quantification of progesterone receptor. The paraffin-embedded specimens fixed in $4 \%$ buffered formalin were used for analysis of immunohistochemical expression of progesterone receptor PR. The slides were heated in citrate buffer, $\mathrm{pH}=9.0$ for $30 \mathrm{~min}$. in a water bath at $96^{\circ} \mathrm{C}$. Next, the sections were incubated for $30 \mathrm{~min}$. at the room temperature in humidified chamber with monoclonal mouse anti-human progesterone receptor antibody (N 1630 Dako, Denmark). The detection of anti-PR antibody was performed using Dako LSAB 2 KIT/HRP. Aminoethylocarbazole (AEC substrate chromogen) was applied to visualize the immunohistochemical reaction. Finally, the sections were counterstained with Mayer's hematoxylin. After each step, the sections were rinsed with Tris-buffered saline (TBS). The control sections were incubated with TBS instead of the primary antibody.

Statistical analysis. Statistical analysis was done by means of the Kruskal-Wallis test. $\mathrm{p}<0.05$ was accepted as the significance level.

\section{Results}

\section{Age of the examined patients}

In group A the mean age of the patients was $46.3 \pm 1.2$ $(\mathrm{M} \pm \mathrm{SD})$, in group B it was $52.4 \pm 3.8(\mathrm{M} \pm \mathrm{SD})$, and in group $\mathrm{C}-58.6 \pm 2.4(\mathrm{M} \pm \mathrm{SD})$. Considerable age differences were observed between women from groups: A and $\mathrm{B}, \mathrm{B}$ and $\mathrm{C}$, and $\mathrm{A}$ and $\mathrm{C}(\mathrm{p}<0.05)$.

\section{The levels of $E_{2}$ and FSH, LH, A, T, DHEAS in serum of the examined patients}

The mean $\mathrm{E}_{2}$, FSH, LH, A, T, DHEAS serum concentrations of the examined patients are illustrated in Table 1. 
Table 1. The levels of $\mathrm{E}_{2}, \mathrm{FSH}, \mathrm{LH}, \mathrm{A}, \mathrm{T}$ and DHEAS in serum of the examined patients (mean $\pm \mathrm{SD}$ ).

\begin{tabular}{|c|c|c|c|c|c|c|}
\hline Group & $\begin{array}{c}\mathrm{F}_{2} \\
(\mathrm{pg} / \mathrm{ml})\end{array}$ & $\begin{array}{c}\mathrm{FSH} \\
(\mathrm{mlU} / \mathrm{ml})\end{array}$ & $\begin{array}{c}\mathrm{I} / \mathrm{H} \\
(\mathrm{mLU} / \mathrm{ml})\end{array}$ & $\begin{array}{c}\Lambda \\
(\mathrm{ng} / \mathrm{ml})\end{array}$ & $\begin{array}{c}\mathrm{T} \\
(\mathrm{ng} / \mathrm{ml})\end{array}$ & $\begin{array}{c}\text { DHFAS } \\
(\mu \mathrm{m} / \mathrm{ml})\end{array}$ \\
\hline $\begin{array}{c}\Lambda \\
\mathrm{N}=25\end{array}$ & $14.15 \pm 9.21$ & $28.60 \pm 15.12$ & $25.15 \pm 9.34$ & $2.64 \pm 1.18$ & $1.9 \pm 0.17$ & $108 \pm 32.43$ \\
\hline $\begin{array}{c}\mathrm{B} \\
\mathrm{N}=15\end{array}$ & $20.55 \pm 6.25$ & $76.45 \pm 20.15^{*}$ & $27.25 \pm 8.15$ & $2.85 \pm 0.65$ & $1.35 \pm 0.07 *$ & $98 \pm 22.4$ \\
\hline $\begin{array}{c}\mathrm{C} \\
\mathrm{N}=10\end{array}$ & $23.18 \pm 8.85$ & $98.15 \pm 14.38^{*}$ & $54.36 \pm 10.12^{*}$ & $1.30 \pm 1.17^{*}$ & $0.77 \pm 0.08^{*}$ & $50 \pm 14.24 *$ \\
\hline
\end{tabular}

means $\pm \mathrm{SD} ; *(\mathrm{p}<0.05)$

The mean $\mathrm{E}_{2}$ serum concentrations did not significantly differ from each other groups, but the mean FSH and $\mathrm{T}$ serum concentrations significantly differ from each other between the examined groups of women (between groups $\mathrm{A}$ and $\mathrm{B}, \mathrm{B}$ and $\mathrm{C}$, and $\mathrm{A}$ and C) and LH, A, DHEAS serum concentrations significantly differ only between group $\mathrm{A}$ and $\mathrm{C}$ and $\mathrm{B}$ and $\mathrm{C}$.

\section{Morphology $(\mathrm{H}+\mathrm{E}$ staining $)$}

In the ovaries of postmenopausal women, the main structural changes in both the cortex and medulla were observed. In the cortex, they were: 1) the reduction of its thickness; 2) emergence of epithelial inclusion cysts; 3 ) the blurred line between medulla and cortex; 4) the increased follicle number; 5) the tendency to fragmentation of corpora albicantia; 6) surface epithelium invaginations. Changes in the medulla included: 1) fibrosis and scars in stroma; 2) architectonical changes in blood vessels with wall hyalinization and lumen constriction. In comparison to groups $\mathrm{A}$ and $\mathrm{B}$, the ovaries of group $\mathrm{C}$ women contained small number of corpora albicantia located in the medullary part as well as thinned blood vessels and few lymphatic vessels and nerves. Our morphological results of the postmenopausal woman ovary (between groups A, B and C) have been already presented [24].

\section{Immunohistochemical results}

PR immunohistochemical localization and immunoexpression in the ovaries of postmenopausal women were shown in Table 2.

In our study, immunohistochemical nuclear expression of PR was revealed in OSE, epithelial inclusion cysts and stromal cells. Immunohistochemical nuclear expression of PR seems to be similar in the ovaries of women who are 5 and 10 years after menopause.

\section{Discussion}

The obtained research results seem to be very interesting. After menopause, localization of PR receptors was
Table 2. Immunohistochemical localization and immunoexpression of PR in the ovaries of postmenopausal women.

\begin{tabular}{|c|c|c|c|}
\hline Patients & $\begin{array}{c}\text { Ovarian surface } \\
\text { cpithelium (OSE) }\end{array}$ & $\begin{array}{c}\text { Epithelial } \\
\text { inclusion cysts }\end{array}$ & $\begin{array}{c}\text { Stromal } \\
\text { cells }\end{array}$ \\
\hline $\begin{array}{c}\text { Group } \\
\text { A }\end{array}$ & $+/+$ & +++ & $++/+++$ \\
\hline $\begin{array}{c}\text { Group } \\
\text { B }\end{array}$ & $+/++$ & +++ & $++/+++$ \\
\hline $\begin{array}{c}\text { Group } \\
\text { C }\end{array}$ & $+/+$ & +++ & $++/+++$ \\
\hline
\end{tabular}

+++ - very strong intensity, ++ - strong intensity, + - week intensity

observed in the ovarian stromal cells, surface epithelium cells and inclusion cysts with metaplastic epithelium. What is more, expression of these receptors did not change depending on the lapse of time from menopause. The reasons for that are not known because in other tissues, ex. adipose tissue, immunoexpression and immunolocalization of PR decreased in women after their last menstruation [21]. It also is not known why our results did not reveal any correlation between the decreasing concentrations of $\mathrm{T}, \mathrm{A}$ and DHEAS and increasing concentrations of FSH and LH, and PR expression in postmenopausal women. Such correlation was reported by other authors, but their research involved women at the reproductive age [7]. After menopause, PR expression was stronger in the skin of those women who had higher DHEAS concentration [21].

A very important thing is the change in the ovarian structure after menopause, especially in the aspect of emergence of epithelial inclusion cysts lined with metaplastic epithelium. These cysts are the most common reason for ovarian cancer development [22]. The obtained results suggest that they contain PR and its expression does not change depending on the time which passed from menopause. The role of this receptor in postmenopausal women is not known. Undoubtedly, it was proved that PR immunoexpression intensifies the proliferation of ductal tubular cells, and thus 

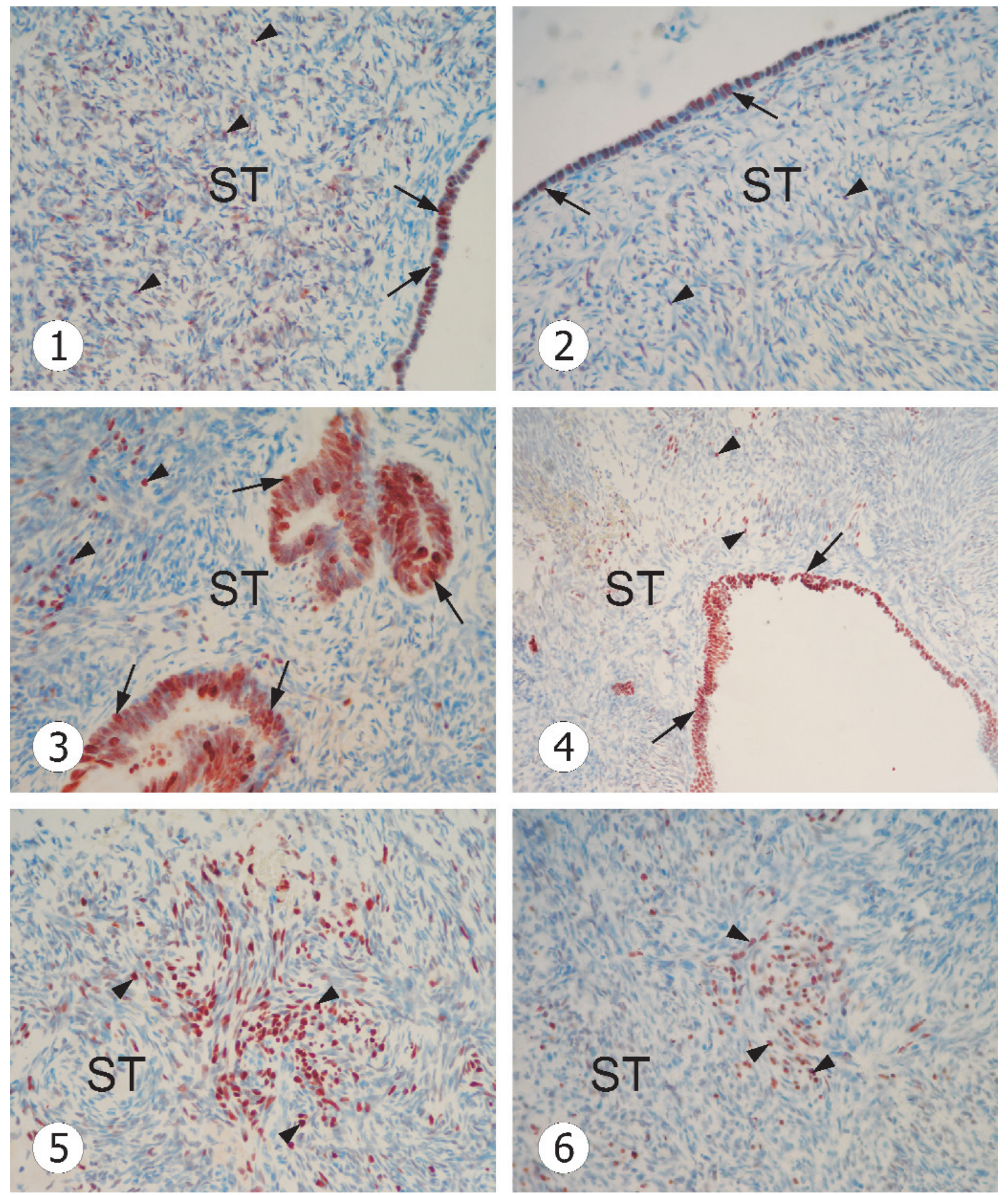

Fig. 1. Immunohistochemical localization and immunoexpression of PR in the ovaries of group A postmenopausal women (examined no more than 5 years after menopause). The expression of PR was observed in some nuclei of ovarian surface epithelium (arrows) and in some stromal cells (arrowheads). Stromal cells (ST) (magnification $\times 400$ ). Fig. 2. Ovary of group C postmenopausal women (examined more than 10 years after menopause). Immunohistochemical localization of PR in some nuclei of ovarian surface epithelium (arrows) and in some stromal cells (arrowheads). Stromal cells (ST) (magnification $\times 400$ ). Fig. 3. Ovary of group A postmenopausal women (examined no more than 5 years after menopause). Immunohistochemical localization of PR. Strong nuclear staining is present in columnar epithelial cells (invaginations of ovarian surface epithelium metaplastic changes, epithelial inclusion cysts) (arrows). Nuclear expression of PR in some stromal cells (arrowheads). Stromal cells (ST) (magnification $\times 400$ ). Fig. 4. Ovary of group C postmenopausal women (examined more than 10 years after menopause). Strong nuclear expression of PR in the epithelial inclusion cyst (arrows) and in some stromal cells (arrowheads). Stromal cells (ST) (magnification $\times 200$ ). Fig. 5. Ovary of group A postmenopausal women (examined no more than 5 years after menopause). Strong nuclear staining is present in some stromal cells (arrowheads). Stromal cells (ST) (magnification $\times 400$ ). Fig. 6. Ovary of group C postmenopausal women (examined more than 10 years after menopause). Strong nuclear staining is present in some stromal cells (arrowheads). Stromal cells $(\mathrm{ST})($ magnification $\times 400)$. 
affects mammary cancer development $[4,10]$. Recently, some articles have been published on the subject of an effect which PR activation have on ovarian cancer development. It was proven that especially PR-As strongly influence proliferation of ovarian epithelial cells [32-34]. These receptors are present in most cases of serous ovarian cancers $[11,12,32]$. It may explain an increase in the incidence of ovarian cancer observed in women using progestagen hormone therapy [21]. To sum up, on the basis of the conducted studies it can be said that in postmenopausal women ovaries, PRs are mainly located in ovarian stromal cells, surface epithelial cells and inclusion cysts with metaplastic epithelium, and expression of these receptors does not change depending on the lapse of time from menopause. Furthermore, PR expression in the ovaries of postmenopausal women does not correlate with T, A, DHEAS and gonadotropin concentrations in blood serum.

Acknowledgements: This paper was supported by the National Committee of Scientific Research (KBN), grant No. PG-2-PO5E10527

\section{References}

[ 1] Leonhardt SA, Boonyaratanakornkit V, Edwards DP. Progesterone receptor transcription and non-transcription signaling mechanisms. Steroids, 2003;68:761-770.

[2] Aso T, Vasavada HA, Kawaguchi T, Germino FJ, Ganguly S, Kitajima S, Weissman SM, Yasukochi Y. Characterization of cDNA for the large subunit of the transcription initiation factor TFIIF. Nature, 1992;355:461-464.

[3] Migliaccio A, Didomenico M, Green S, Defalco A, Kajtaniak EL, Blasi F, Chambon P, Auricchio F. Phosphorylation on tyrosine of in vitro synthesized human estrogen receptor activates its hormone binding. Mol Endocrinol, 1989;3:1061-1069.

[ 4] Fendrick JL, Raafat AM, Haslam SZ. Mammary gland growth and development from the postnatal period to postmenopause: ovarian steroid receptor ontogeny and regulation in the mouse. J Mammary Gland Biol Neoplasia, 1998;3: 7-22.

[ 5] Juengel JL, Heath DA, Laurel DQ, McNatty KP. Oestrogen receptor $\alpha$ and $\beta$, androgen receptor and progesterone receptor mRNA and protein localization within the developing ovary and in small growing follicles of sheep. Reprod, 2006; 131:81-92.

[ 6] Saarikoski S, Selander K, Kallio S, Pystynen P. Steroid receptors in normal and neoplastic female reproductive tissues. Gynecol Obstet Invest, 1982;13:206-212.

[7] Słomczyńska M, Krok M, Pierściński A. Localization of the progesterone receptor in the porcine ovary. Acta Histochem, 2000;102:183-191.

[ 8] Khan MS, Dodson AR, Heatley MK. Ki-67, oestrogen receptor, and progesterone receptor proteins in the human rete ovary and in endometriosis. J Clin Pathol, 1997; 52:517-520.

[ 9] Butnor KJ, Burchette JL, Robboy SJ. Progesterone receptor activity in leiomyomatosis peritonealis disseminata. Int $J$ Gynecol Pathol, 1999;18:259-264.

[10] Richer JK, Jacobsen BM, Manning NG, Abel MG, Wolf DM, Horwitz KB. Differential gene regulation by the two progesterone receptor isoforms in human breast cancer cells. $J$ Biol Chem, 2002;15:5209-5218.
[11] Kanajet D, Klarić P, Bolf-Benković L Estrogen and progesterone receptors in ovarian carcinoma. Jugosl Ginekol Perinatol, 1985;25:13-16.

[12] Li AJ, Baldwin RL, Karlan BY. Estrogen and progesterone receptor subtype expression in normal and malignant ovarian epithelial cell cultures. Am J Obstet Gynecol, 2003;189:22-27.

[13] Marshburn PB, Zhang J, Bahrani-Mostafavi Z, Matthews ML, White J, Hurst BS. Variant progesterone receptor mRNAs are co-expressed with the wild-type progesterone receptor mRNA in human endometrium during all phases of the menstrual cycle. Mol Hum Reprod, 2005;11:809-815.

[14] Niwa K, Imai A, Hashimoto M, Yokoyama Y, Mori H, Matsuda Y, Tamaya T. A case-control study of uterine endometrial cancer of pre- and post-menopausal women. Oncol Rep, 2000;7:89-93.

[15] Flötotto T, Niederacher D, Hohmann D, Heimerzheim T, Dall P, Djahansouzi S, Bender HG, Hanstein B. Molecular mechanism of estrogen receptor (ER)alpha-specific, estradioldependent expression of the progesterone receptor (PR) B-isoform. J Steroid Biochem Mol Biol, 2004;88:131-142.

[16] Tung L, Abdel-Hafiz H, Shen T, Harvell DM, Nitao LK, Richer JK, Sartorius CA, Takimoto GS, Horwitz KB. Progesterone receptors (PR)-B and -A regulate transcription by different mechanisms: AF-3 exerts regulatory control over coactivator binding to PR-B. Mol Endocrinol, 2006;20:26562670.

[17] Conneely OM, Mulac-Jericevic B, Lydon JP. Progesteronedependent regulation of female reproductive activity by two distinct progesterone receptor isoforms. Steroids, 2003;68: 771-778.

[18] Chakraborty TR, Gore AC. Aging-related changes in ovarian hormones, their receptors, and neuroendocrine function. Exp Biol Med, 2004;229:977-987.

[19] Yoshimura Y, Bahr JM. Localization of progesterone receptors in pre-and postovulatory follicles of the domestic hen. Endocrinology, 1991;128:323-330.

[20] Ciereszko R, Dusza L. Exogenus prolactin elevates plasma progesterone concetrations and reduces androgen concetrations during early luteal phase of the porcine estrous cycle. Animal Reprod Sci, 1993;31:141-154.

[21] Meza-Munoz DE, Fajardo ME, Perez-Luque EL, Malacara JM. Factors associated with estrogen recsptors-alpha (ERalpha) and -beta (ER-beta) and progesterone receptor abundance in obese and non obese pre- and post-menopausal women. Steroids, 2006;6:498-503.

[22] Auersperg N, Wong AS, Choi KC, Kang SK, Leung PC. Ovarian surface epithelium: biology, endocrinology and pathology. Endocr Rev, 2001; 22:255-288.

[23] Słomczyńska M. The dynamic of the steroid hormone receptors distibution in the ovary. Post Biol Kom, 2002;29:27-46.

[24] Brodowska A, Laszczyńska M, Starczewski A. Apoptosis in ovarian cells in postmenopausal women. Folia Histochem Cytobiol, 2007;45:99-105.

[25] Simpson E, Rubin G, Clyne C, Robertson K, O Donnell L, Davis S, Jones M. Local estrogen biosyntesis in males and females. Endocrine-Related. Cancer, 1999;6:131-137.

[26] Wright JW, Stouffer RL, Rodland KD. Hight-dose estrogen and clinical selective estrogen receptor modulators induce growth arrest, p-21, and p-53 in primate ovarian surface epithelial cells. J Clin Endocrinol Metab, 2001;90:36883695.

[27] Vang R, Gown AM, Barry TS, Wheeler DT, Ronnet BM. Immunohistochemistry for estrogen and progesterone receptors in the distinction of primary and metastatic mucinous tumors in the ovary: an analysis of 124 causes. Modern Pathol, 2006;19:97-105.

[28] Vanderhyden BC. Loss of ovarian function and the risk of ovarian cancer. Cell Tissues Res, 2005;322:117-124. 
[29] Brodowska A, Starczewski A, Laszczyńska M, Szydłowska I. Androgeneza jajnikowa u kobiet po menopauzie. Pol Merk Lek, 2005;19:90-93.

[30] Brodowska A, Laszczyńska M, Starczewski A, Karakiewicz $\mathrm{B}$, Brodowski J. Localization and function of the estrogen receptor $\alpha$ in the ovaries of postmenopausal women ovary. Folia Histochem Cytobiol, 2007:45:325-330.

[31] Pepe GJ, Billiar RB, Leavitt MG, Zachos NC, Gustafsson JA, Albrecht ED. Expression of estrogen receptors $\alpha$ and $\beta$ in the baboon fetal ovary. Biol Reprod, 2002;66:1054-1060.

[32] Akahira J, Suzuki T, Ito K, Kaneko C, Darnel AD, Moriya T, Okamura K, Yaegashi N, Sasano H. Differential expression of progesterone receptor isoforms A and B in the normal ovary, and in benign, borderline, and malignant ovarian tumors. . Jpn J Cancer Res. 2002;93:807-815.
[33] Narayanan R, Edwards DP, Weigel NL. Human progesterone receptor displays cell cycle-dependent changes in transcriptional activity. Mol Cell Biol, 2005;25:2885-2898.

[34] Romano A, Delvoux B, Fischer DC, Groothuis P. The PROGINS polymorphism of the human progesterone receptor diminishes the response to progesterone. J Mol Endocrinol, 2007;38:331-350.

[35] Hirata S, Shoda T, Kato J, Hoshi K. Novel isoforms of the mRNA for human female sex steroid hormone receptors. J Steroid Biochem Mol Biol, 2002; 83: 25-30

Submitted: 17 January, 2008 Accepted after reviews: 8 April, 2008 